\title{
Optimization of ionic liquid-microwave assisted extraction method of Mahkota Dewa (Phaleria macrocarpa (Scheff.) Boerl.) fruit pulp
}

\author{
Rosita Handayani, Wulan Purnamasari, Abdul Mun'im* \\ Faculty of Pharmacy, Universitas Indonesia, Depok, West Java, Indonesia.
}

\begin{tabular}{l}
\hline ARTICLE INFO \\
\hline Received on: $15 / 03 / 2020$ \\
Accepted on: $31 / 10 / 2020$ \\
Available online: 05/02/2021 \\
\hline Key words: \\
Antioxidant, BF4; IL-MAE, \\
ionic liquid, Mahkota \\
dewa, microwave, Phaleria \\
macrocarpa.
\end{tabular}

\section{INTRODUCTION}

Phaleria macrocarpa (PMp), locally known as Mahkota dewa, is an endemic plant of Indonesia which has been used for a long time as a medicine to cure a variety of diseases such as cancer, liver, heart, diabetes, arthritis, kidney, stroke, and hypertension (Daud et al., 2016; Hendra et al., 2011). The fruit pulp of $P$. macrocarpa (PMp) contains a variety of secondary metabolites. Various previous studies have been conducted to investigate and prove its benefits as a preventive therapy in cancer and hypertension. From these studies, it is known that the compound group which plays an important role is the phenolic group compound. The phenolic compound is the highest content

\author{
${ }^{*}$ Corresponding Author \\ Abdul Mun'im, Faculty of Pharmacy, Universitas Indonesia, Depok, West \\ Java,Indonesia.E-mail:munim @farmasi.ui.ac.id
}

consisting of mahkoside, phalerin, benzophenone, mangiferin, and kaempferol-3-O- $\beta$-glycoside compounds (Oshimi et al., 2008; Yanti et al., 2014; Zhang et al., 2012). The pulp of PMp is known to be fibrous and watery (Figure 1); the main fibrous components consist of cellulose, hemicellulose, lignin, $\beta$-glucan, gums, pectin, and hydrocolloid (Lay et al., 2014). The high fiber content makes the extraction process of beneficial compounds more difficult and it requires special treatment.

Some of the methods have been conducted in PMp extraction including maceration, soxhlet, reflux, and supercritical fluid extraction (Alara and Olalere, 2016). The extraction process using microwaves is also being considered. Microwave-assisted extraction (MAE) involves interference at the internal structure of cells. The exposure of microwave creates heat and high temperature inside of the cell matrix, resulting in the cell friction and the release of active constituents (Chen et al., 2017; Ekezie et al., 2017; Delazar et al, 2012). By using this technique, the beneficial compounds in the plant will be extracted easily. 


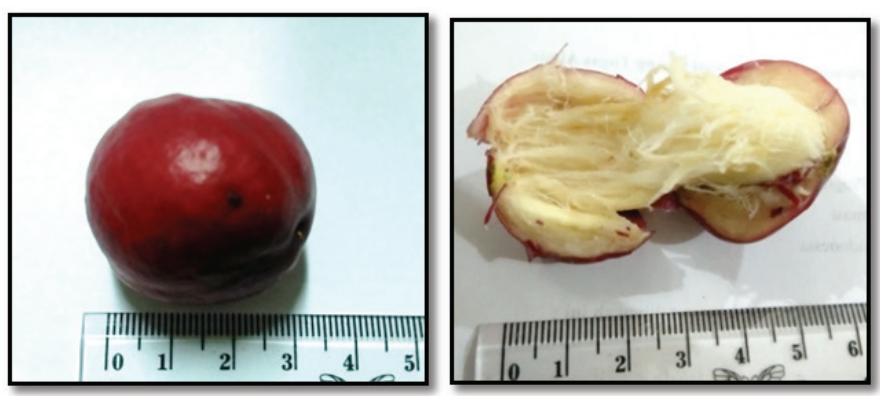

Figure 1. Fruit of Mahkota dewa (Phaleria macrocarpa (Scheff.) Boerl.).

In line with the development of the extraction method, the usages of ecofriendly solvents are also being developed. Ionic liquid (IL) is one of the common solvents explored. IL is an organic salt in the liquid form consisting of organic cations and organic or inorganic anions. The combination of MAE with IL is often used as an alternative extraction technique for extracting active substances of medicinal plants; this method becomes more popular as IL-MAE (Chen et al., 2017).

Another strategy in compound extraction from plants is reducing the lignin and hemicellulose contents, confounding the structure of plant cell walls for increasing solvent access in the cell matrix (Sun et al., 2016). This strategy is known as pretreatment. Pretreatment was commonly being used with chemicals, such as urea. In a previous study, it was mentioned that adding the urea with alkaline solutions in pretreatment can increase the solubility of cellulose (Isobe et al., 2013; Xiong et al., 2013). Adding urea as a base added before extraction is believed to increase the extraction results.

This research was carried out to obtain the IL-MAE optimum condition compared to the other conventional extraction techniques, such as reflux, soxhlet, and extraction with urea pretreatment. The results of the study are expected to be used as preliminary data in determining the suitable extraction methods to produce optimum extracts in terms of extraction efficiency which is measured through TPC and antioxidant activity of the sample.

\section{MATERIALS AND METHODS}

\section{Plant material}

The dried fruit pulp of Mahkota dewa (P. macrocarpa (Scheff.) Boerl) has been obtained from Purworejo, Central Java, Indonesia, and has been identified by Lembaga Ilmu Pengetahuan Indonesia (LIPI), Pusat Penelitian Biologi, Cibinong, Central Java, with voucher code 817.

\section{Chemicals}

[BMIM]BF ${ }_{4}$ (Shanghai Cheng Jie Chemical Co., China), $\mathrm{Na}_{2} \mathrm{CO}_{3}, \mathrm{KH}_{2} \mathrm{PO}_{4}, \mathrm{NaCl}$ (Brataco, Indonesia), urea (Harum Chemistry), ethyl acetate proanalysis, methanol proanalysis, methanol HPLC grade, distilled water (Merck), gallic acid reference with purity $>98.5 \%$ (Sigma-Aldrich Co., USA), sodium carbonate (Sigma-Aldrich Co., USA), Folin-Ciocalteu reagent (Sigma-Aldrich Co., USA), BHT, and DPPH reagent (SigmaAldrich Co., USA) were used.

\section{Instruments}

Design-Expert ${ }^{\mathrm{TM}}$ version 10.0 .0 data processor, microwave (Modena) modified for MAE, high-performance liquid chromatography (Shimadzu LC-20AT), 0,45 mm (Agilent) micropore filter, UV-Vis detector (Shimadzu SPD-20 A), microsyringe $50 \mu \mathrm{l}$ (Hamilton), C18 column (ZORBAX Eclipse), microplate 96 flat bottom (Thermo Scientific), microplate reader (Versa Max), centrifugator (Labsco), and vortex (WiseMix) were used.

\section{Soxhlet extraction}

Dried and pulverized fruit pulp (20 g) were extracted in $70 \%$ ethanol for 6 hours using a soxhlet apparatus. The resulting mixture was allowed to cool overnight to yield the optimum content of phenolic compounds. The extract was dried with a rotary vacuum evaporator and then in a vacuum oven at $40^{\circ} \mathrm{C}$. The TPC was measured using a microplate reader at $750 \mathrm{~nm}$ using a method previously conducted by Bobo-Garcia (2015).

\section{Reflux extraction}

Similar to the soxhlet extraction, $20 \mathrm{~g}$ of the sample was extracted in $200 \mathrm{ml}$ of $70 \%$ ethanol for 2 hours at $80^{\circ} \mathrm{C}$ using a reflux apparatus. The resulting mixture was evaporated under vacuum at $50^{\circ} \mathrm{C}$ and subsequently dried at $40^{\circ} \mathrm{C}$ in a vacuum oven to obtain the crude extract. TPC was measured as described in the previous sections.

\section{Determination of salt in Aqueous Biphasic System (ABS)}

$1 \mathrm{~g}$ PMp powder was mixed with $20 \mathrm{ml}$ of $0.5 \mathrm{M}$ [BMIM] $\mathrm{BF}_{4}$ solution for 5 minutes and was centrifuged at 3,000 rpm for 15 minutes. Supernatant was filtered and partitioned with ethyl acetate and added with $0.01 \mathrm{M} \mathrm{Na}_{2} \mathrm{CO}_{3}, \mathrm{KH}_{2} \mathrm{PO}_{4}$, or $\mathrm{NaCl}$ with a molar ratio of $1: 1 \mathrm{v} / \mathrm{v}$. The solution was mixed and centrifuged at 3,000 rpm for 10 minutes. The ethyl acetate phase was taken and was evaporated using a drying oven at $50^{\circ} \mathrm{C}$ (Ayuningtyas et al., 2017). TPC was measured using a microplate reader at $750 \mathrm{~nm}$ using a method previously conducted by Bobo-Garcia (2015). The yield was calculated. An extract that shows the highest yield and TPC was further selected for optimization with response surface methodology.

\section{IL-MAE extraction}

\section{Experimental design}

The optimization of extraction conditions was carried out using Design-Expert ${ }^{\circledR}$ software version 10.0 .0 by selecting the Box-Behnken method. Three extraction parameters (concentration (M), extraction time (minutes), and ratio solvent: sample) were determined and showed in Table 1. From the set parameter, 17 run extraction designs have been obtained (Table 2).

\section{IL-MAE extraction}

Extraction was carried out in 17 conditions (runs) as showed in Table 2. 1 gof PMp powder was extracted in the microwave for 5 minutes at $10 \%$ power and under the conditions (parameters) as specified in Table 2 for each run. The extract obtained was fractionated using ethyl acetate and selected salt 
solution (0.01 $\left.\mathrm{M} \mathrm{KH}_{2} \mathrm{PO}_{4}\right)$ which was previously achieved at the determination of salt in the ABS step. The ethyl acetate fraction was collected and dried in a drying oven at $50^{\circ} \mathrm{C}$ for 2 days. The yield and TPC were calculated.

\section{Antioxidant activity assay}

Antioxidant activity assay was performed using a microplate reader conducted by Bobo-Garcia, 2015 method. The absorbance was measured at $517 \mathrm{~nm}$. Antioxidant activity was determined through the percentage of DPPH radical-scavenging activity using the following equation:

$$
A=\text { absorbance. }
$$

\section{Chromatogram profile analysis}

Chromatogram profile investigation of PMp extract was carried out by the HPLC method according to Winarno et al. (2010) using column (C-18), mobile phase (acetonitrile:water for injection:acetic acid (89:10:1)), flow rate (1 ml/minute), detector (UV, at $254 \mathrm{~nm}$ for quercetin, $280 \mathrm{~nm}$ for benzophenone and mahkoside, and $288 \mathrm{~nm}$ for mangiferin), and injection volume $(20 \mu \mathrm{l})$.

\section{Pretreatment using urea}

Pretreatment was carried out using $1 \mathrm{~g} \mathrm{PMp}$ and $8 \%$ urea (w/w gram of PMp powder). The volume was adjusted $10 \mathrm{ml}$ with

Table 1. IL-MAE parameters of optimization.

\begin{tabular}{ccccc}
\hline \multirow{2}{*}{ No. } & Factors & \multicolumn{3}{c}{ Level } \\
\cline { 3 - 5 } & & -1 & 0 & +1 \\
\hline 1. & IL concentration (M) & 0.5 & 1.0 & 1.5 \\
2. & Solvent: sample ratio & 12.5 & 15 & 17.5 \\
3. & Extraction time (min) & 1.5 & 2.5 & 3.5 \\
\hline
\end{tabular}

demineralized water (Jin et al., 2007). The immersion with urea was carried out for 12 hours based on a preliminary experiment. After pretreatment, the sample was extracted with [BMIM] $\mathrm{BF}_{4} 0.5$ $\mathrm{M}$ for 5 minutes and was partitioned with $\mathrm{KH}_{2} \mathrm{PO}_{4}$ (Ayuningtyas et al., 2017). TPC and antioxidant activity were determined (BoboGarcia, 2015).

\section{RESULTS AND DISCUSSION}

Ionic liquids are solvents that should not be consumed; therefore, before the extract can be consumed, the extract must be partitioned first from the ionic liquid solvent to induce the saltingout process during partition. The process of extract partition from solvent IL is called an ABS, also known as the aqueous twophase system. ABS is formed from the contact of two immiscible solvents. The principle is the selective distribution of compounds between two phases (Shukla et al., 2017). ABS consists of polymer combinations: salt polymer, salt in water solutions, and solvents which immiscible with water, such as ethyl acetate (Wu et al., 2016). The ABS usage in the separation of compounds from ionic liquids was first performed by using [BMIM]Cl as ionic liquids and $\mathrm{K}_{3} \mathrm{PO}_{4}$ as inorganic salt (Gutowski et al., 2013). In this research, $\mathrm{KH}_{2} \mathrm{PO}_{4}$ salt produces the highest TPC $(71.69 \pm 1.17 \mathrm{mg} \mathrm{GAE} / \mathrm{g}$ $\mathrm{PMp}$ powder) compared to carbonate and chloride salt (Figure 2). This finding is in line with previous research with different samples which showed that $\mathrm{KH}_{2} \mathrm{PO}_{4}$ salt can be used for liquid partitions because it will induce salting out immediately after application. $\mathrm{KH}_{2} \mathrm{PO}_{4}$ salt is easy to form $\mathrm{ABS}$ with hydrophobic ionic liquids and induce the formation of an Aqueous Biphasic System (Mourao et al., 2012).

The yield of IL-MAE extraction was directly proportional to TPC. Run 11 showed the highest yield and TPC, while run 8 has the lowest yield and TPC (Table 2). Run 11 yielded $684.3 \mathrm{mg} / \mathrm{g}$ powder containing $191.72 \pm 1.27 \mathrm{mg}$ GAE$/ \mathrm{g}$ powder.

Table 2. TPC of several conditions.

\begin{tabular}{|c|c|c|c|c|c|}
\hline Run & $\begin{array}{c}\text { Concentration } \\
\qquad(M)\end{array}$ & $\begin{array}{l}\text { Extraction time } \\
\quad \text { (minutes) }\end{array}$ & $\begin{array}{c}\text { Ratio solvent: sample } \\
(\mathrm{ml} / \mathrm{g})\end{array}$ & $\begin{array}{c}\text { Total yield } \\
\text { (mg/g powder) }\end{array}$ & $\begin{array}{c}\text { TPC (mg GAE/g } \\
\text { powder) }\end{array}$ \\
\hline 1 & 1 & 1.5 & 12.5 & 171.5 & $67.37 \pm 0.35$ \\
\hline 2 & 1 & 2.5 & 15 & 229 & $92.69 \pm 1.30$ \\
\hline 3 & 1 & 2.5 & 15 & 247 & $92.96 \pm 0.53$ \\
\hline 4 & 1 & 2.5 & 15 & 256,4 & $93.18 \pm 1.18$ \\
\hline 5 & 0.5 & 2.5 & 17.5 & 104.3 & $52.90 \pm 1.04$ \\
\hline 6 & 1 & 2.5 & 15 & 216.2 & $90.30 \pm 1.19$ \\
\hline 7 & 1 & 2.5 & 15 & 328.5 & $92.47 \pm 1.62$ \\
\hline 8 & 0.5 & 2.5 & 12.5 & 42.4 & $34.10 \pm 0.20$ \\
\hline 9 & 1 & 1.5 & 17.5 & 395.2 & $146.91 \pm 1.64$ \\
\hline 10 & 1.5 & 1.5 & 15 & 554.8 & $180.18 \pm 1.67$ \\
\hline 11 & 1.5 & 2.5 & 17.5 & 684.3 & $191.72 \pm 1.27$ \\
\hline 12 & 1.5 & 3.5 & 15 & 570 & $167.88 \pm 2.09$ \\
\hline 13 & 1 & 3.5 & 17.5 & 374.2 & $137.32 \pm 2.67$ \\
\hline 14 & 0.5 & 1.5 & 15 & 85.3 & $40.94 \pm 0.23$ \\
\hline 15 & 1.5 & 2.5 & 12.5 & 342 & $157.79 \pm 2.29$ \\
\hline 16 & 0.5 & 3.5 & 15 & 73.7 & $46.85 \pm 0.23$ \\
\hline 17 & 1 & 3.5 & 12.5 & 178.8 & $74.09 \pm 0.91$ \\
\hline
\end{tabular}




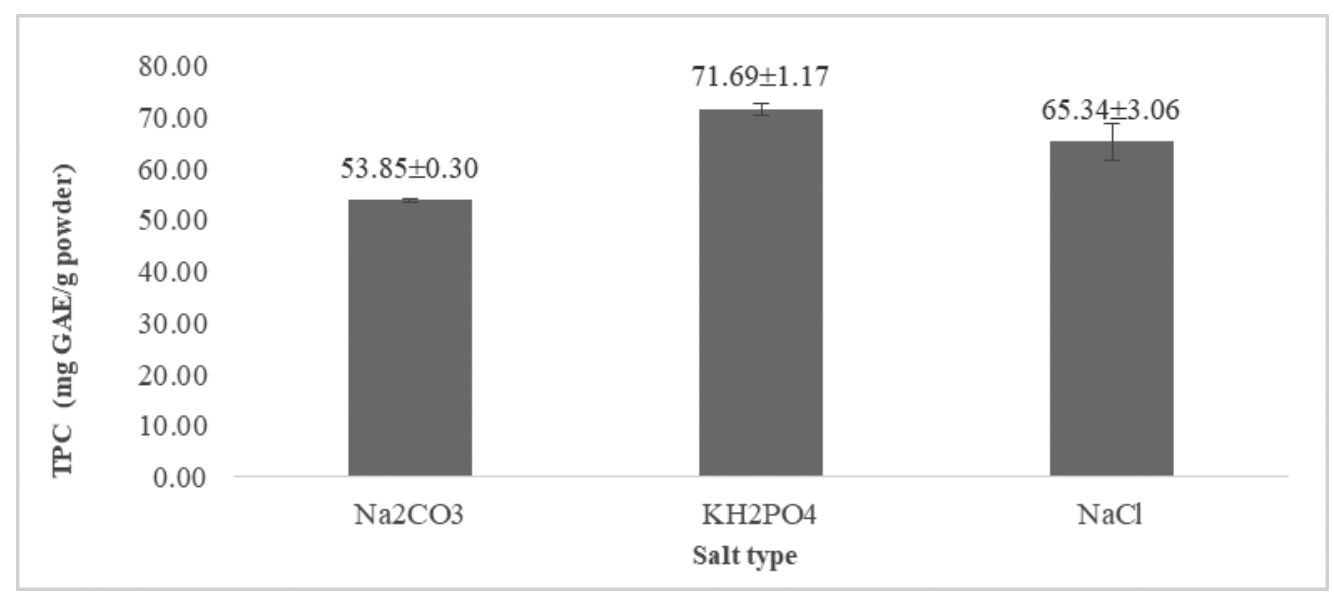

Figure 2. TPC in three types of salt.

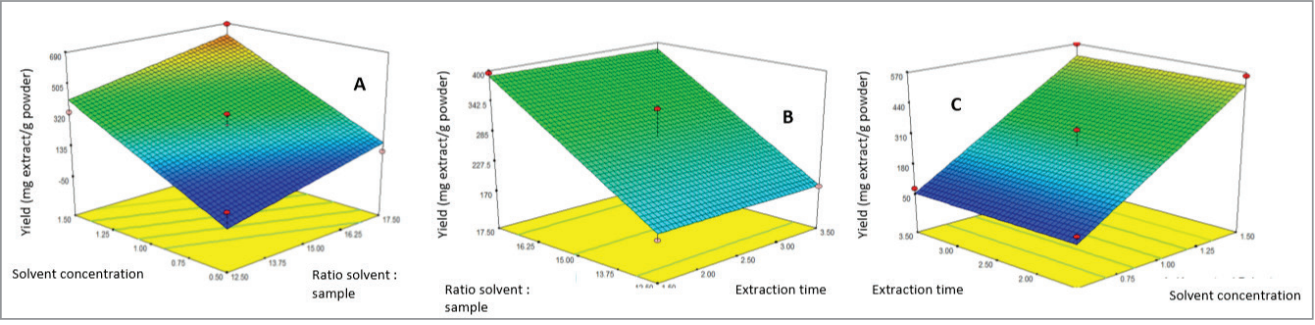

Figure 3. Surface response graph showed the yield (mg/g powder) of two parameters. (a) Solvent: sample ratio and solvent concentration. (b) Solvent: sample ratio and extraction time. (c) Solvent concentration and extraction time.

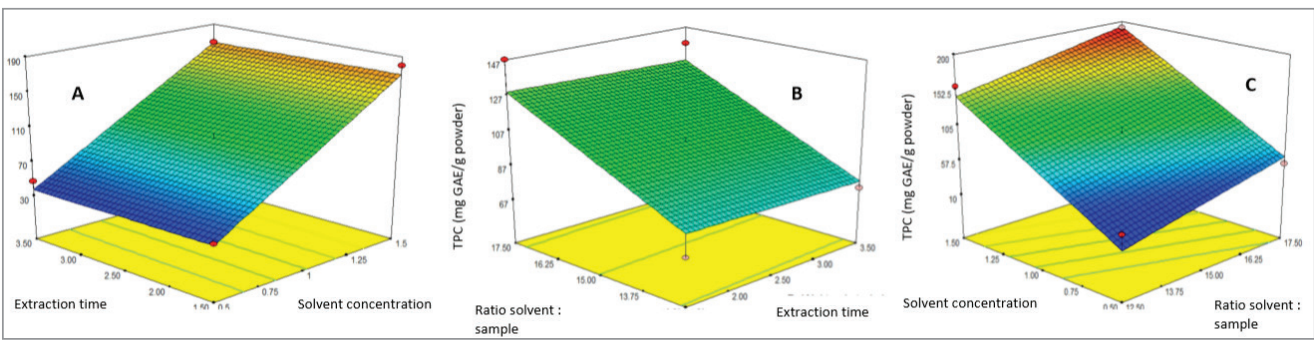

Figure 4. Surface response graph showed the TPC of two parameters. (a) Solvent concentration and extraction time. (b) Solvent: sample ratio and time. (c) Solvent: sample ratio and solvent concentration.

The surface response graph was demonstrated in Figures 3 and 4 (optimum conditions are shown in red-yellow on the graph). In the yield and TPC analysis, significant parameters that affect yield and TPC are solvent concentration and solvent-sample ratio because their " $p$-value" is less than 0.0001 , while the extraction time is not significant because the value of " $p$ " is more than 0.1 .

TPC resulting from IL-MAE in optimum conditions (run 11) was compared with TPC resulting from reflux and soxhlet extraction. IL-MAE produced a higher TPC than TPC in conventional methods (Figure 5). This finding indicates that the optimization of IL-MAE extraction has succeeded in more increasing TPC almost five times than conventional extraction. In the previous studies, 1-Butyl-3-methylimidazolium tetrafluoroborate ([BMIM] $\mathrm{BF}_{4}$ ) was used to extract phenolics, flavonoids, and phenolic alkaloids using Ultrasonic Assisted Extraction, Microwave-Assisted Extraction, and conventional extraction method (Tang et al., 2012). Lu et al. (2008) found that $[\mathrm{BMIM}] \mathrm{BF}_{4}$ is the most efficient and selective solvent in extracting phenolic compounds. The separation mechanism is based on the hydrogen-bonding interaction between IL's anion and the $-\mathrm{OH}$ group of phenolic compounds (Lu et al., 2008).

The IL-MAE efficiency for extracting PMp containing lignin and cellulose has been strengthened by the results of TPC and antioxidant activity comparison in extraction using $8 \%$ urea. The results obtained from TPC and antioxidant activity in samples given urea (pretreatment) are higher than nonpretreatment extraction in optimum condition (Table 4). This result is consistent with the literature which stated that urea addition can increase cellulose solubility and yield of extraction (Xiong et al., 2014). Urea is an additional chemical of the cellulose dissolution process in alkalic conditions. The addition of urea increases the cellulose dissolved fraction in 


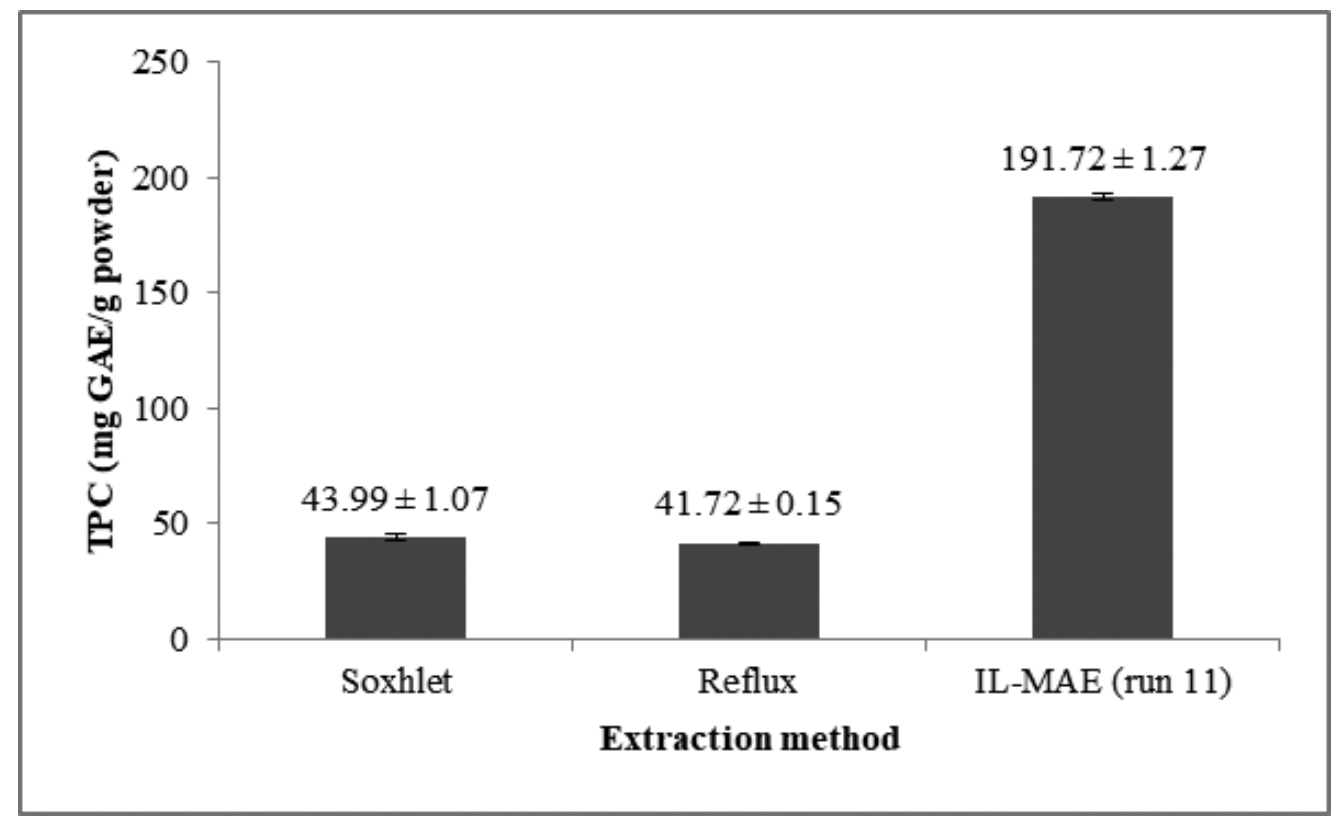

Figure 5. TPC in different methods: soxhlet, reflux, and IL.

Table 3. Chromatogram profile analysis results.

\begin{tabular}{|c|c|c|c|c|c|c|c|c|c|c|c|c|c|}
\hline \multirow{2}{*}{$\begin{array}{l}\text { Wavelength }(\lambda) \\
\text { Peak }\end{array}$} & & \multicolumn{2}{|c|}{$254 \mathrm{~nm}$} & \multicolumn{4}{|c|}{$280 \mathrm{~nm}$} & \multicolumn{6}{|c|}{$288 \mathrm{~nm}$} \\
\hline & & tR & Area & $\mathbf{t R}_{1}$ & Area $_{1}$ & $\mathrm{tR}_{2}$ & Area $_{2}$ & $\mathbf{t R}_{1}$ & Area $_{1}$ & $\mathbf{t R}_{2}$ & Area $_{2}$ & $\mathbf{t R}_{3}$ & Area $_{3}$ \\
\hline \multirow{4}{*}{ Quercetin } & Reff & 5.962 & 1557 & & & & & & & & & & \\
\hline & IL-MAE & 6.144 & 20858 & & & & & & & & & & \\
\hline & Reflux & 6.006 & 214996 & & & & & & & & & & \\
\hline & Soxhlet & 6.096 & 183502 & & & & & & & & & & \\
\hline Benzophenone & Reff & & & 8.171 & 3863 & 11.338 & 1008 & & & & & & \\
\hline \multirow[t]{5}{*}{ Mahkoside } & Reff & & & 8.134 & 540 & 11.286 & 745 & & & & & & \\
\hline & IL-MAE & & & 8.195 & 9250 & 11.374 & 1338 & & & & & & \\
\hline & Reflux & & & 8.131 & 12842 & 11.305 & 6583 & & & & & & \\
\hline & Soxhlet & & & 8.159 & 1573 & 11.382 & 4711 & & & & & & \\
\hline & Reff & & & & & & & 9.806 & 1588 & 10.714 & 1391 & 11.168 & 1558 \\
\hline \multirow{3}{*}{ Mangiferin } & IL-MAE & & & & & & & 9.76 & 1264 & 10.832 & 1516 & none & none \\
\hline & Reflux & & & & & & & none & None & 10.744 & 4198 & 11.237 & 2145 \\
\hline & Soxhlet & & & & & & & 9.857 & 1390 & None & None & 11.137 & 6523 \\
\hline
\end{tabular}

$*$ Reff $=$ refference

tR: time retention in minutes.

Table 4. The effect of pretreatment on TPC and antioxidant activity.

\begin{tabular}{lcc}
\hline Sample & TPC (mg GAE/g powder) & DPPH-scavenging activity (\%) \\
\hline Pretreatment & $124.47 \pm 1.05$ & $20.26 \pm 0.002$ \\
Nonpretreatment & $191.72 \pm 1.27$ & $12.1 \pm 0.003$ \\
\hline
\end{tabular}

solvents by $1.5-2.5$ times and the solution thermal stability (Isobe et al., 2013). However, the TPC value in pretreatment and nonpretreatment is not much different. Pretreatment by using urea takes 12 hours, while IL-MAE only takes 2.5 minutes in processing time. By considering the time efficiency, extraction using IL-MAE at optimum conditions produces superior results among all the methods in this study.
IL-MAE efficiency has been qualitatively compared with conventional extraction methods through chromatogram profile in HPLC analysis. The analysis was conducted using acetonitrile: water for injection: acetic acid (89:10:1) as mobile phase, considering the polarity of polyphenolic marker compounds (quercetin, benzophenone, mahkoside, and mangiferin). Figure 6 showed quercetin in minute 5.96, benzophenone, mahkoside in minutes 8 and 11, and mangiferin in minute 9.80; 10.71; and 11.17. Chromatogram profile extract from IL-MAE showed more selective results than reflux and soxhlet; there is no peak detected in minutes 12-14 (at $254 \mathrm{~nm}$ ), in minutes 10-11 (at $280 \mathrm{~nm}$ ), and in minutes 8-9 (at $288 \mathrm{~nm}$ ) compared to reflux and soxhlet method (Figure 6). 
$\mathrm{mV}$

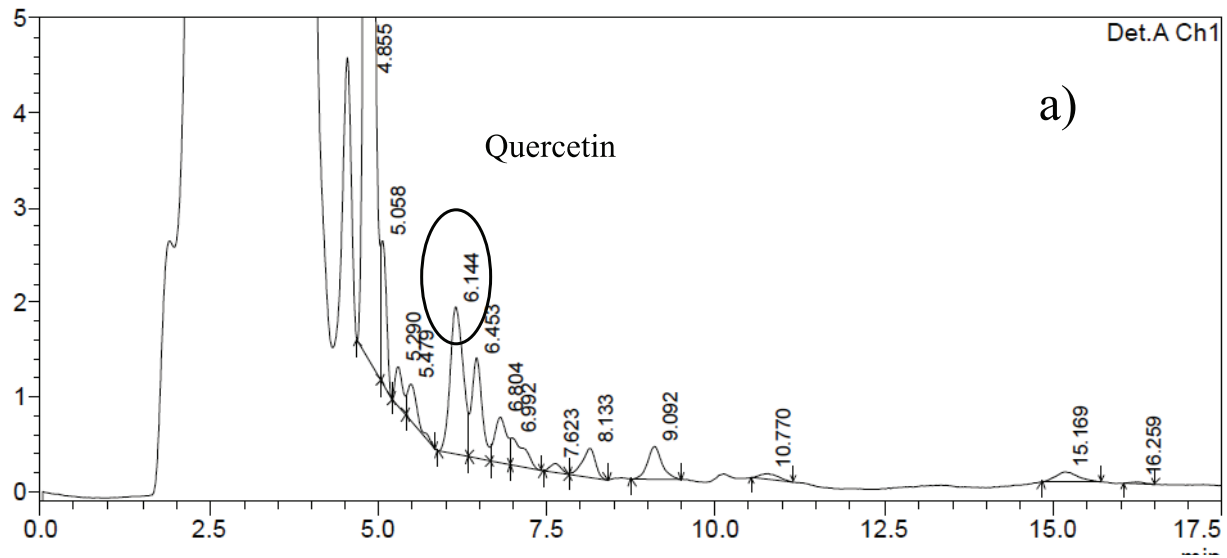

$\mathrm{mV}$

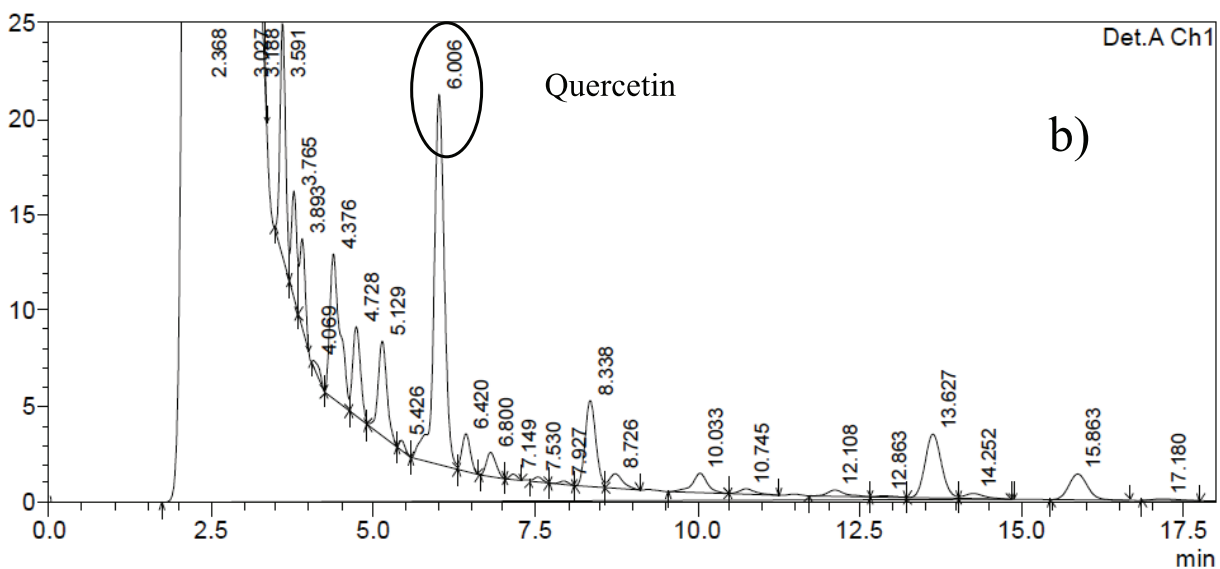

$\mathrm{mV}$

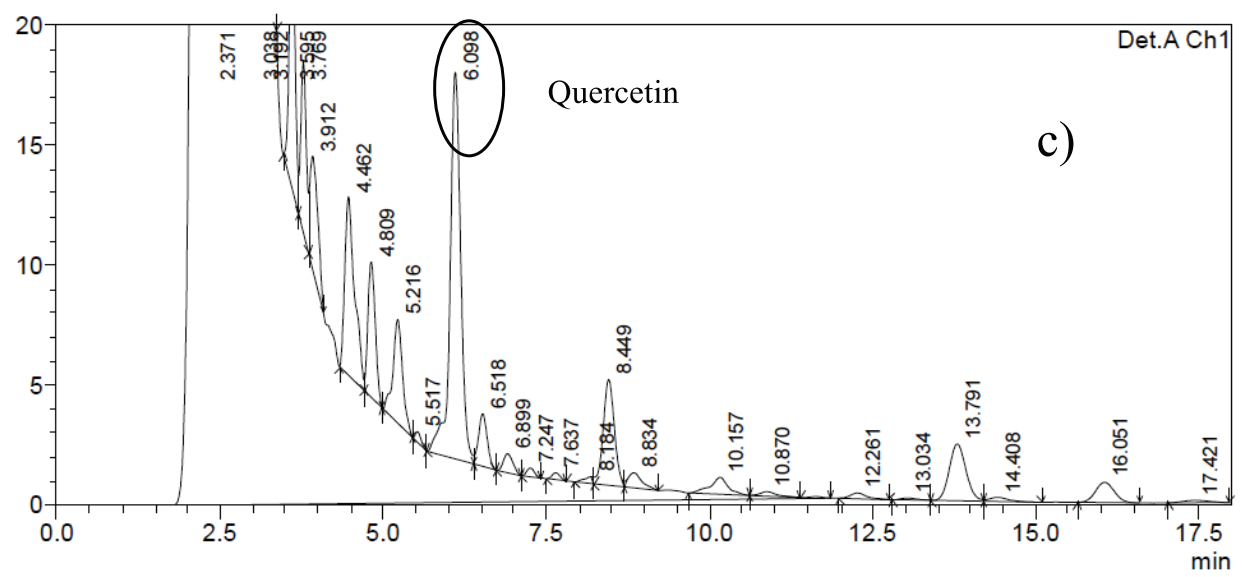

Figure 6. Chromatogram profile: (a) IL-MAE, (b) reflux, and (c) soxhlet (at $254 \mathrm{~nm}$ ).

\section{ACKNOWLEDGMENTS}

All authors acknowledge Universitas Indonesia and Hibah PUTI Q3 for support.

\section{CONFLICTS OF INTEREST}

The authors report no financial or any other conflicts of interest in this work.

\section{FUNDING}

This Research was funded by Hibah PUTI Q3 Universitas Indonesia.

\section{AUTHOR CONTRIBUTIONS}

All authors made substantial contributions to conception and design, acquisition of data, or analysis and interpretation of data; took part in drafting the article or revising it critically for important intellectual content; agreed to submit to the current journal; gave final approval of the version to be published; and agree to be accountable for all aspects of the work.

\section{ETHICAL APPROVALS}

This study does not involve the use of animals or human subjects. 


\section{ABBREVIATIONS}

DPPH: 1,1-diphenyl-2-picrylhydrazyl, GAE: gallic acid equivalent, IL: ionic liquid, IL-MAE: ionic liquid-microwave assisted extraction, PMp: Phaleria macrocarpa fruit pulp, TPC: total phenolic content.

\section{PUBLISHER'S NOTE}

This journal remains neutral with regard to jurisdictional claims in published institutional affiliation.

\section{REFERENCES}

Alara O, Olarere O. A critical overview on the extraction of bioactive compounds from Phaleria macrocarpa (Thymelaceae). Nat Prod Chem Res, 2016; 4(5); doi:10.4172/2329-6836.1000232

Ayuningtyas IN, Rahmawati M, Sutriyo, Mun'im A. Optimization of ionic liquid-based microwave assisted extraction to obtain trans-resveratrol from Gnetum gnemon L. Seeds. J Young Pharm, 2017; 9(4):457-62; doi:10.5530/jyp.2017

Bobo-García G, Davidov-Pardo G, Arroqui C, Vírseda P, MarínArroyo MR, Navarro M. Intra-laboratory validation of microplate methods for total phenolic content and antioxidant activity on polyphenolic extracts, and comparison with conventional spectrophotometric methods. J Sci Food Agric, 2015; 95(1):204-9; doi:10.1002/jsfa.6706

Chen F, Mo K, Zhang Q, Fei S, Zu Y, Yang L. A novel approach for distillation of paeonol and simultaneous extraction of paeoniflorin by microwave irradiation using an ionic liquid solution as the reaction medium. Sep Purif Technol, 2017; 183:73-82; doi:10.1016/j.seppur.2017.03.069

Daud D, 'Amirah Badruzzaman N, Sidik NJ, Tawang A. Phaleria macrocarpa fruits methanolic extract reduces blood pressure and blood glucose in spontaneous hypertensive rats (SHR). J Appl Pharm Sci, 2016; 6(1):158-61; doi:10.7324/JAPS.2016.600126

Ekezie FGC, Sun DW, Cheng JH. Acceleration of microwaveassisted extraction processes of food components by integrating technologies and applying emerging solvents: a review of latest developments. Trends Food Sci Technol, 2017; 67:160-72; doi:10.1016/j.tifs.2017.06.006

Gutowski KE, Broker GA, Willauer HD, et al. Controlling the aqueous miscibility of ionic liquids: aqueous biphasic systems of watermiscible ionic liquids and water-structuring salts for recycle, metathesis, and separations. J Am Chem Soc, 2003; 125(22):6632-3; doi:10.1021/ ja0351802

Hendra R, Ahmad S, Oskoueian E, Sukari A, Shukor MY. Antioxidant, anti-inflammatory and cytotoxicity of Phaleria macrocarpa (Boerl.) Scheff Fruit. BMC Complement Altern Med, 2011; 11:110. Published 2011 Nov 9; doi:10.1186/1472-6882-11-110.

Isobe N, Noguchi K, Nishiyama Y, Kimura S, Wada M, Kuga S. Role of urea in alkaline dissolution of cellulose. Cellulose, 2013; 20(1):97103; doi:10.1007/s10570-012-9800-7

Jin H, Zha C, Gu L. Direct dissolution of cellulose in $\mathrm{NaOH} /$ thiourea/urea aqueous solution. Carbohydr Res, 2007; 342(6):851-8; doi:10.1016/j.carres.2006.12.023

Lay MM, Karsani SA, Mohajer S, Abd Malek SN. Phytochemical constituents, nutritional values, phenolics, flavonols, flavonoids, antioxidant and cytotoxicity studies on Phaleria macrocarpa (Scheff.) Boerl fruits. BMC Complement Altern Med, 2014; 14(1):1-12; doi:10.1186/1472-6882$14-152$
Lu Y, Ma W, Hu R, Dai X, Pan Y. Ionic liquid-based microwaveassisted extraction of phenolic alkaloids from the medicinal plant Nelumbo nucifera Gaertn. J Chrom A, 2008; 1208:42-6; doi:10.1016/j. chroma.2008.08.070

Mourão T, Cláudio AFM, Boal-Palheiros I, Freire MG, Coutinho JAP. Evaluation of the impact of phosphate salts on the formation of ionicliquid-based aqueous biphasic systems. J Chem Thermodyn, 2012; 54:398 405; doi:10.1016/j.jct.2012.05.019

Oshimi S, Zaima K, Matsuno Y, Hirasawa Y, Iizuka T, Studiawan $\mathrm{H}$, Indrayanto G, Zaini NC, Morita H. Studies on the constituents from the fruits of Phaleria macrocarpa. J Nat Med, 2008; 62(2):207-10; doi:10.1007/ s11418-007-0209-9

Shukla SK, Pandey S, Pandey S. Applications of ionic liquids in biphasic separation: Aqueous biphasic systems and liquid-liquid equilibria J Chromatogr A, 2018; 1559:44-61; doi:10.1016/j.chroma.2017.10.019

Sun S, Sun S, Cao X, Sun R. The role of pretreatment in improving the enzymatic hydrolysis of lignocellulosic materials. Bioresour Technol, 2016; 199:49-58; doi:10.1016/j.biortech.2015.08.061

Tang B, Bi W, Tian M, Row KH. Application of ionic liquid for extraction and separation of bioactive compounds from plants. J Chromatogr B, 2012; 904:1-21; doi:10.1016/j.jchromb.2012.07.020

Delazar A, Nahar L, Hamedeyazdan S, Sarker SD. Microwaveassisted extraction in natural products isolation. Methods Mol Biol 2012;864:89-115

Winarno EK, Mazda, Rahmawati H, Winarno H. Pengaruh Iradiasi Gamma Pada Aktivitas Sitotoksik Daging Buah Mahkota Dewa (Phaleria macrocarpa (Scheff) Boerl.). J Sains dan Teknol Nukl Indones, 2010; 11(2):67-76.

Wu H, Yao S, Qian G, Song H. Development of tropine-salt aqueous two-phase systems and removal of hydrophilic ionic liquids from aqueous solution. J Chromatogr A, 2016; 1461:1-9; doi:10.1016/j. chroma.2016.06.081

Xiong B, Zhao P, Hu K, Zhang L, Cheng G. Dissolution of cellulose in aqueous $\mathrm{NaOH} / \mathrm{urea}$ solution: role of urea. Cellulose, 2014 21(3):1183-92; doi:10.1007/s10570-014-0221-7

Yanti AR, Radji M, Mun'im A, Suyatna FD. Effects of the Methanol extracts Phaleria macrocarpa ( Scheff) Boerl fruits on Angiotensin Converting Enzyme ( ACE ) activity. Int Jounal Adv Pharmacy, Biol Chem, 2014; 3(4):912-8.

Zhang SY, Zhang QH, Zhao W, Zhang X, Zhang Q, Bi Y-F, Zhang Y-B. Isolation, characterization and cytotoxic activity of benzophenone glucopyranosides from Mahkota Dewa (Phaleria macrocarpa (Scheff.) Boerl). Bioorganic Med Chem Lett, 2012; 22(22):6862-6; doi:10.1016/j. bmcl.2012.09.038

How to cite this article:

Handayani R, Purnamasari W, Mun'im A. Optimization of ionic liquid-microwave assisted extraction method of Mahkota Dewa (Phaleria macrocarpa (Scheff.) Boerl.) fruit pulp. J Appl Pharm Sci, 2021; 11(02):059-065. 